\title{
Tubuca alcocki, a new pseudocryptic species of fiddler crab from the Indian Ocean, sister to the southeastern African T. urvillei (H. Milne Edwards, 1852) (Crustacea, Decapoda, Brachyura, Ocypodidae)
}

\author{
Hsi-Te Shih', Benny K.K. Chan², Peter K.L. Ng \\ I Department of Life Science and Research Center for Global Change Biology, National Chung Hsing Univer- \\ sity, 250, Kuo Kuang Road, Taichung 402, Taiwan 2 Biodiversity Research Center, Academia Sinica, Taipei \\ 115, Taiwan 3 Lee Kong Chian Natural History Museum, National University of Singapore, 6 Science Drive \\ 2, Singapore 117546, Republic of Singapore \\ Corresponding author: Benny K. K. Chan (chankk@gate.sinica.edu.tw)
}

Academic editor: Sammy De Grave | Received 7 January 2018 | Accepted 10 February 2018 | Published 29 March 2018

http://zoobank.org/A2A19CC3-B61A-4B64-AD85-583D736DFDF0

Citation: Shih H-T, Chan BKK, Ng PKL (2018) Tubuca alcocki, a new pseudocryptic species of fiddler crab from the Indian Ocean, sister to the southeastern African T. urvillei (H. Milne Edwards, 1852) (Crustacea, Decapoda, Brachyura, Ocypodidae). ZooKeys 747: 41-62. https://doi.org/10.3897/zookeys.747.23468

\begin{abstract}
A new pseudocryptic species of fiddler crab, Tubuca alcocki sp. n., is described from the northern Indian Ocean. The new species was previously identified with T. urvillei (H. Milne Edwards, 1852), but can be distinguished by the structures of the anterolateral angle of the carapace and male first gonopod. The molecular data of the mitochondrial cytochrome oxidase subunit I gene shows that both are sister taxa and the divergence time is estimated at 2.2 million years ago, around the beginning of the Pleistocene. While the new species is widely distributed in the northern part of Indian Ocean, occurring from the Red Sea to India and the Andaman Sea; T. urvillei sensu stricto has a more restricted range, and is known only from southeastern Africa.
\end{abstract}

\section{Keywords}

mitochondrial cytochrome oxidase subunit I, molecular clock, morphology, new species, Tubuca alcocki, Tubuca urvillei

Copyright Hsi-Te Shih et al. This is an open access article distributed under the terms of the Creative Commons Attribution License (CC BY 4.0), which permits unrestricted use, distribution, and reproduction in any medium, provided the original author and source are credited. 


\section{Introduction}

In recent years, various genetic and morphological studies on fiddler crabs (Ocypodidae) from the Indian Ocean have shown that there are a number of species endemic to the region: Austruca albimana (Kossmann, 1877), A. bengali (Crane, 1975), A. iranica (Pretzmann, 1971), A. occidentalis (Naderloo, Schubart \& Shih, 2016), A. sindensis (Alcock, 1900), Cranuca inversa (Hoffmann, 1874), Paraleptuca chlorophthalmus (H. Milne Edwards, 1837), Gelasimus hesperiae (Crane, 1975), and Tubuca urvillei (H. Milne Edwards, 1852) (Shih et al. 2009, 2010, 2012, 2013a,b, 2015, 2016; Naderloo et al. 2016). The genetics suggest that the cladogenesis of these taxa have their origins in the Indian Ocean.

Of these taxa, Tubuca urvillei is a large-sized species, which has been widely reported from throughout the Indian Ocean and is the only Tubuca Bott, 1973 species known in the western Indian Ocean (Crane 1975; Shih et al. 2016). Aspects of its biology has also been investigated in southeastern Africa (e.g., Macnae 1963; Hartnoll 1975; Litulo 2005; Peer et al. 2015), Thailand (e.g., Jaroensutasinee et al. 2003; Jaroensutasinee and Jaroensutasinee 2004), and Pakistan (Ghory and Siddiqui 2006).

In this study, specimens from the range of Tubuca urvillei, including the type specimens, were examined. There are two clades, with small but consistent morphological differences supported by DNA evidence from cytochrome oxidase subunit I (COI). The material from the northern and eastern parts of the Indian Ocean is herein described as a new pseudocryptic species, T. alcocki.

\section{Materials and methods}

Specimens of Tubuca urvillei sensu lato collected from southeastern Africa, India and western Thailand examined (including the types) are deposited in the Muséum national d'Histoire naturelle, Paris, France (MNHN); Zoological Collections of the Department of Life Science, National Chung Hsing University, Taichung, Taiwan (NCHUZOOL); Senckenberg Museum, Frankfurt am Main, Germany (SMF); and Zoological Reference Collection of the Lee Kong Chian Natural History Museum (formerly Raffles Museum of Biodiversity Research), National University of Singapore, Singapore (ZRC). The abbreviation G1 is used for male first gonopod. Measurements, all in millimeters $(\mathrm{mm})$, are of the maximum carapace width $(\mathbf{C W})$, carapace length (CL) and pollex length (PL). The terminology used essentially follows Crane (1975) and Davie et al. (2015).

Sequences of COI were obtained following the method described by Shih et al. (2016), after verification with the complimentary strand. Sequences of the different haplotypes have been deposited in the DNA Data Bank of Japan (DDBJ) (accession numbers in Table 1). According to Shih et al. (2016), T. urvillei is sister to the clade composed of T. dussumieri (H. Milne Edwards, 1852), T. paradussumieri (Bott, 1973) and T. capricornis (Crane, 1975). As a result, the sequences of these three species, as published in Shih et al. (2016) (LC150436, LC053373 and LC150430), are used as outgroups in this paper. 
Table I. The haplotypes of COI gene of Tubuca alcocki sp. n. and T. urvillei from the Indian Ocean. Abbreviations of museums or universities see Material and methods.

\begin{tabular}{|c|c|c|c|c|}
\hline Species & Locality & Catalogue no. & $\begin{array}{c}\text { Sample } \\
\text { size }\end{array}$ & $\begin{array}{c}\text { Access. no. } \\
\text { of COI }\end{array}$ \\
\hline \multirow{7}{*}{$\begin{array}{l}\text { Tubuca alcocki } \\
\text { sp. n. }\end{array}$} & \multirow[t]{2}{*}{ India: Mumbai } & $\begin{array}{c}\text { NCHUZOOL 14899, } 14925, \\
\text { 14901, } 14902\end{array}$ & S & LC150445 \\
\hline & & NCHUZOOL 14903 & 2 & LC150445 \\
\hline & \multirow{3}{*}{ Thailand: Ranong } & ZRC (paratype) & 2 & LC369625 \\
\hline & & NCHUZOOL 14896 (paratype) & 1 & LC369625 \\
\hline & & ZRC 2017.1278 (holotype) & 1 & LC369625 \\
\hline & \multirow{2}{*}{ Thailand: Phuket } & ZRC 1999.1131 & 1 & LC369625 \\
\hline & & ZRC 1999.1131 & 1 & LC369626 \\
\hline \multirow{3}{*}{ Tubuca urvillei } & Mayotte: Poroani & ZRC 1999.1107 & 1 & LC053375 \\
\hline & Kenya: Shimo la Tewa & SMF 19985 & 1 & LC053375 \\
\hline & $\begin{array}{c}\text { Kenya: Mida Creek, } \\
\text { Malindi } \\
\end{array}$ & NCHUZOOL 14895 & 1 & LC053375 \\
\hline
\end{tabular}

The phylogenetic tree was reconstructed by the maximum likelihood (ML) analysis by using RAxML (vers. 7.2.6, Stamatakis 2006), with the model GTR + G (i.e. GTRGAMMA) was used with 100 runs, and found the best ML tree by comparing the likelihood scores. The robustness of the ML tree was evaluated by 1000 bootstrap pseudoreplicates under the model GTRGAMMA. Basepair (bp) difference, as well as the pairwise estimates of Kimura 2-parameter (K2P) distance (Kimura 1980) and the uncorrected p-distance for genetic diversities between haplotypes were also calculated by MEGA (vers. 7.0, Kumar et al. 2016).

\section{Systematic account}

Family Ocypodidae Rafinesque, 1815

Subfamily Gelasiminae Miers, 1886 (sensu Shih et al. 2016)

Genus Tubuca Bott, 1973

\section{Tubuca urvillei (H. Milne Edwards, 1852)}

Figures 1, 2, 4B, 5E-H, 7B, D, F, H

Gelasimus arcuatus - Krauss 1843: 39 [Natal Bay, South Africa] (not Ocypode (Gelasimus) arcuata De Haan, 1835).

Gelasimus urvillei H. Milne Edwards, 1852: 148, pl. 3(10) [type locality: "Vanikoro"]; Kingsley 1880: 145 [list]; De Man 1891: 21, 34 [Nossy Faly, Madagascar]; Ortmann 1894: 59 [Dar es Salaam, Tanzania].

Gelasimus dussumieri - A. Milne-Edwards 1868: 71 [list; Zanzibar]; Hilgendorf 1869: 84, pl. 4(1) [Zanzibar]; Hoffmann 1874: 17-18, pl. 3(19-22) [part; Nossy Faly, Madagascar]; De Man 1880: 68 [part; Madagascar]; Kingsley 1880: 145 [list; 
part]; Lenz and Richters 1881: 423 [Madagascar]; Pfeffer 1889: 30 [Zanzibar]; De Man 1891: 20, 26 [part; Nossy Faly, Madagascar]; Lenz 1910: 559 [Zanzibar; Pemba] (not Gelasimus dussumieri H. Milne Edwards, 1852).

Uca arcuata - Stebbing 1905: 40 [South Africa]; Stebbing 1910: 327 [list] (not Ocypode (Gelasimus) arcuata De Haan, 1835).

Uca arcuatus - Stebbing 1917: 15 [Natal, South Africa] (not Ocypode (Gelasimus) arcuata De Haan, 1835).

Uca dussumieri - Maccagno 1928: 17-19 [part; Giumbo, Somalia] (not Gelasimus dussumieri $\mathrm{H}$. Milne Edwards, 1852).

Uca urvillei - Barnard 1950: 93-94, figs 18d-f, 19a-b; Fourmanoir 1954: 3 [Madagascar]; Macnae 1963: 23 [Inhaca I., Mozambique to Cape Province, South Africa]; Richmond 1997: 226, 2 unnumbered figs on p. 227 [eastern Africa]; Crosnier 1965: 110-112, figs 186, 191-193, 195-196; Kensley 1981: 49 [list]; Rosenberg 2001: 860, 868 [South Africa]; Serbino 2008: 62-72, fig. 1 [Mozambique].

Tubuca urvillei - Bott 1973: fig. 11; Shih et al. 2016: 159 [list; part].

Uca (Uca) urvillei - Hartnoll 1975: 308, 310, 322, 324, fig. 8 [Tanzania].

Uca (Uca) dussumieri - Hartnoll 1975: 308, 310 [list; Tanzania] (not Gelasimus dussumieri $\mathrm{H}$. Milne Edwards, 1852).

Uca (Deltuca) [coarctata] urvillei - Crane 1975: 58-61, figs 7, 8D, 9D, 27G-H, 38UX, 62E, 75, pl. 9A-B, E-H [part, southeastern Africa].

Uca (Deltuca) urvillei - Vannini and Valmori 1981: 212-213, figs 5F1, F2, 6F [Giumbo, Somalia].

Uca (Tubuca) urvillei - Bouchard et al. 2013: 46, fig. 40 (Mayotte); Peer et al. 2014: 60, fig. 15; 2015: 190, 198, fig. 4c, d (upper figure) [South Africa].

Material examined. Lectotype $\hat{\sigma}(\mathrm{CW} 18.5 \mathrm{~mm}, \mathrm{CL} 11.0 \mathrm{~mm}, \mathrm{PL} 17.0 \mathrm{~mm}$ ) (MNHN B.12073), "Vanikoro", coll. J. R. C. Quoy and J. P. Gaimard (Fig. 1A-E). Paralectotypes: 2 우 (MNHN B. 3208), same data as lectotype (Fig. 1F-G).

Other material. $1 \delta$ (CW $28.5 \mathrm{~mm}$ ), 1 q (CW $22.9 \mathrm{~mm}$ ) (SMF 19985), Shimo la Tewa, ca. $20 \mathrm{~km}$ N Mombasa, ca. 2 km von Küste entfernt, Schlickmangrove, Kenya, coll. H. Langer, 11 Aug. 1990; 1 ठ (CW 29.7 mm) (ZRC 1999.1107), Poroani, mangrove to the south, Mayotte, 23 July 1998; 2 ô $\widehat{\text { o }}$ (CW 27.9-34.9 mm), NCHUZOOL 14895, Mida Creek, Malindi, Kenya.

Diagnosis. Male. Carapace (Figs 1A, 2A, 4B, 7B, D, F) with anterolateral angle (= external orbital angle) broadly triangular, directed laterally; anterolateral margin short to moderately long; dorsolateral margin long, definite, strongly converging; 1 posterolateral stria. Floor of orbit with row of fewer than 17 tubercles, sometime with blunt ridge (Figs 1B, 2C, D). Major cheliped (Figs 1C, 2B) with dactylus usually longer than palm, outer surface of dactylus and pollex each with 1 long groove proximally extending beyond midlength. Fingers of minor cheliped without conspicuous tooth on either finger. G1 (Fig. 5E-H) with distal tube relatively stout, distinctly curved, gently tapering towards tip, distal part distinctly narrower than proximal part; thumb of moderate length, extending beyond base of distal tube. Female. Carapace with anterolateral an- 


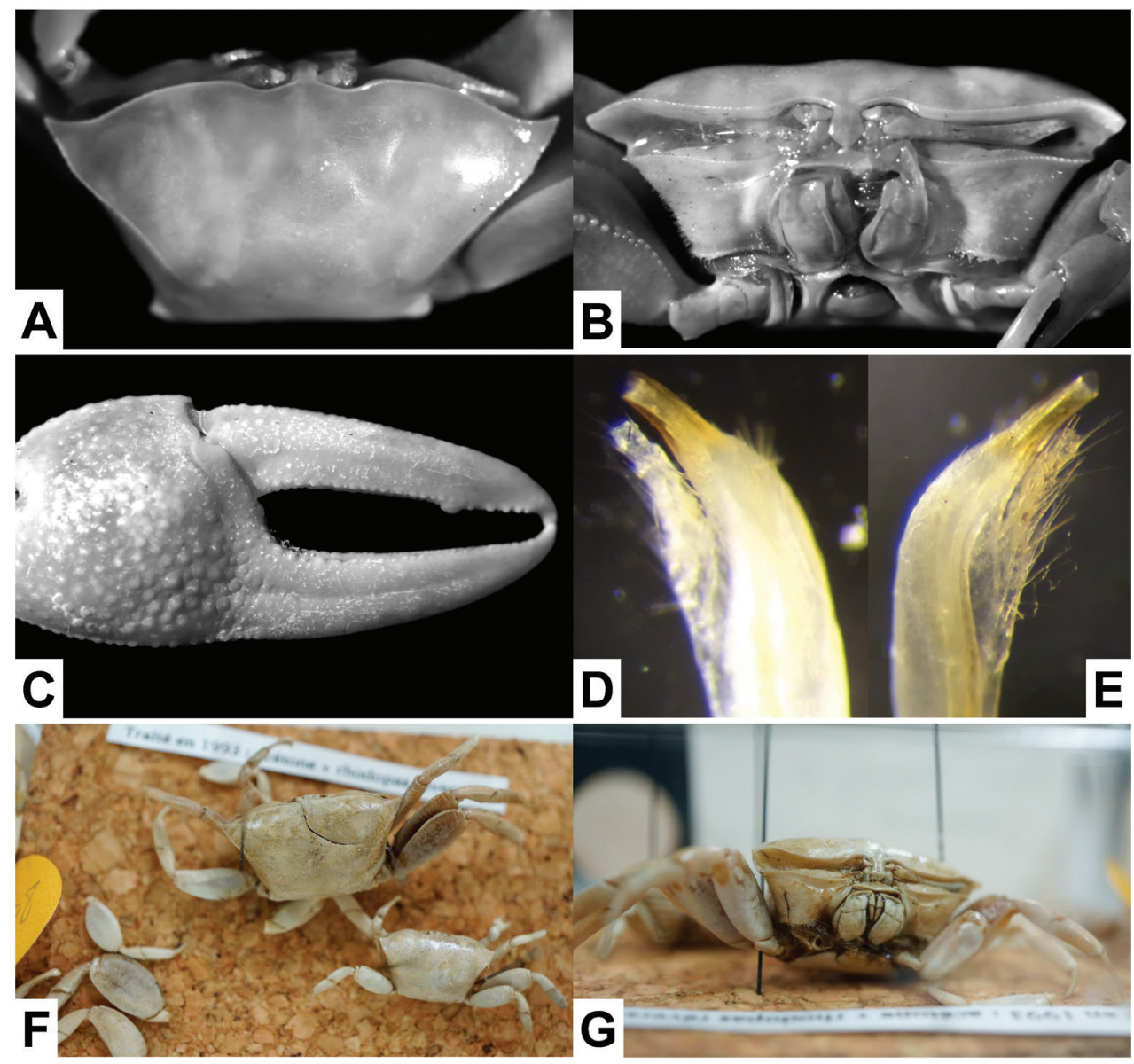

Figure I. Tubuca urvillei (H. Milne Edwards, 1852). A-E lectotype (CW 18.5 mm, PL 17 mm, MNHN B.12073) F-G 2 dried female paralectotypes (MNHN B. 3208). A dorsal view B frontal view $\mathbf{C}$ major cheliped D, E distal part of right G1. D mesial view E lateral view.

gle acutely triangular; anterolateral margin short or absent, joining dorsolateral margin as almost straight line (Fig. 7H). Floor of orbit with row of 14-16 tubercles (Fig. 2F). Fingers of cheliped (Fig. 2F) each with conspicuous tooth on occlusal margin. (See also Remarks under T. alcocki sp. n. for comparisons of morphology and colouration.)

Distribution. Southeastern Africa from Giumbo (= Jumboo), southern Somalia, to Cape Province, South Africa (mouth of Umtata R.); Madagascar (Crane 1975).

Remarks. In his revision of the genera and subgenera of the fiddler crabs of the world, Bott (1973) established Tubuca and designated Gelasimus urvillei H. Milne Edwards, 1852 as the type species from the lectotype (Bott 1973: fig. 11). The type specimens of Tubuca urvillei were supposedly collected from "Vanikoro" (an island between Solomon and Vanuatu) in the western Pacific. Crane (1975) queried this type locality noting that the species as she understood it did not occur outside the In- 


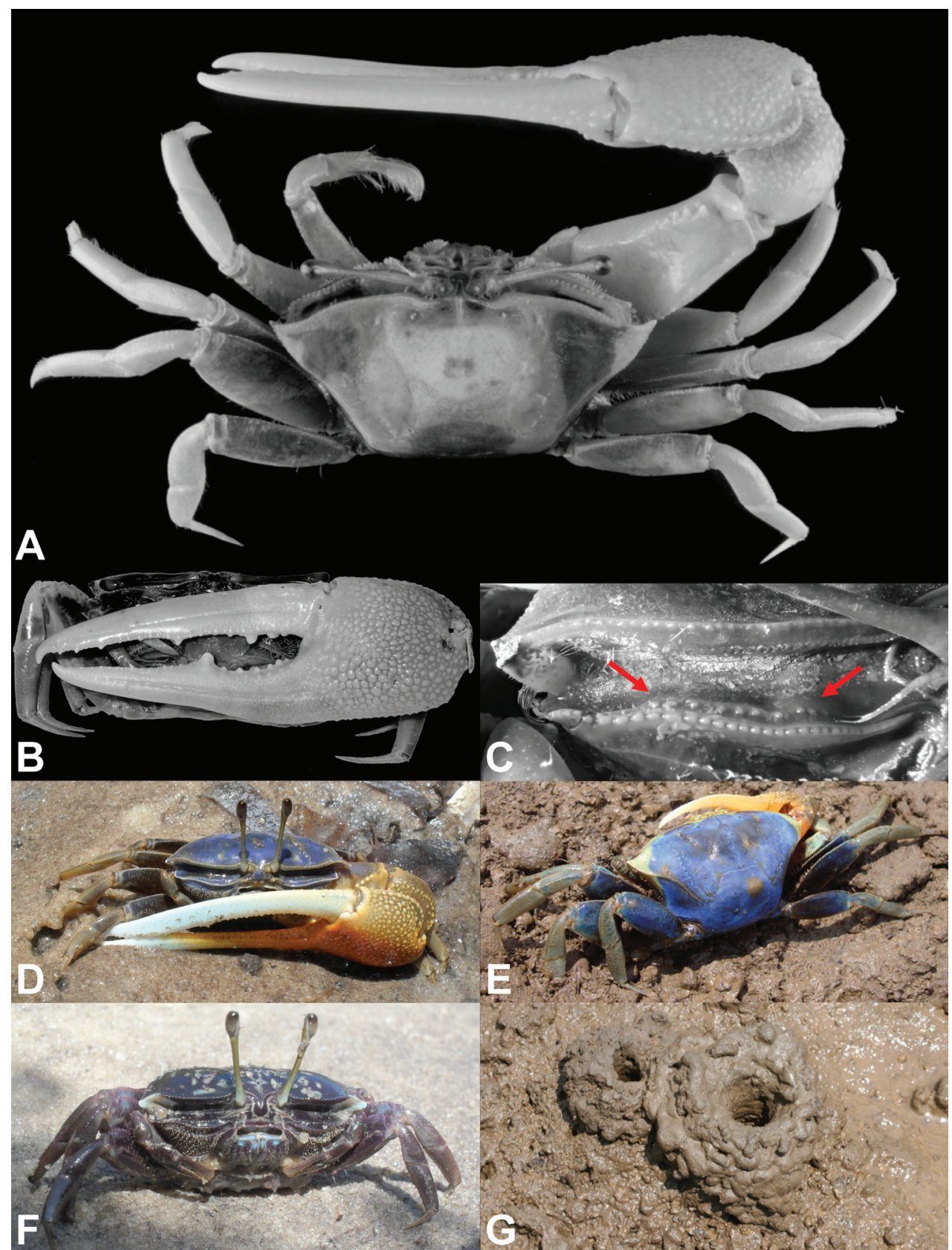

Figure 2. Tubuca urvillei (H. Milne Edwards, 1852) A male (CW 29.7 mm, ZRC 1999.1107; Mayotte) B-C male (CW 34.9, NCHUZOOL 14895; Kenya). A dorsal view B major cheliped C floor of right orbit of showing the tubercles (arrowed). D-F live colouration. D male from Kenya $\mathbf{E}$ male from Mayotte $\mathbf{F}$ female from Kenya $\mathbf{G}$ chimneys built by T. urvillei in Mayotte $\mathbf{D}, \mathbf{F}$ courtesy of S. Cannicci $\mathbf{E}, \mathbf{G}$ courtesy of J. Poupin. 


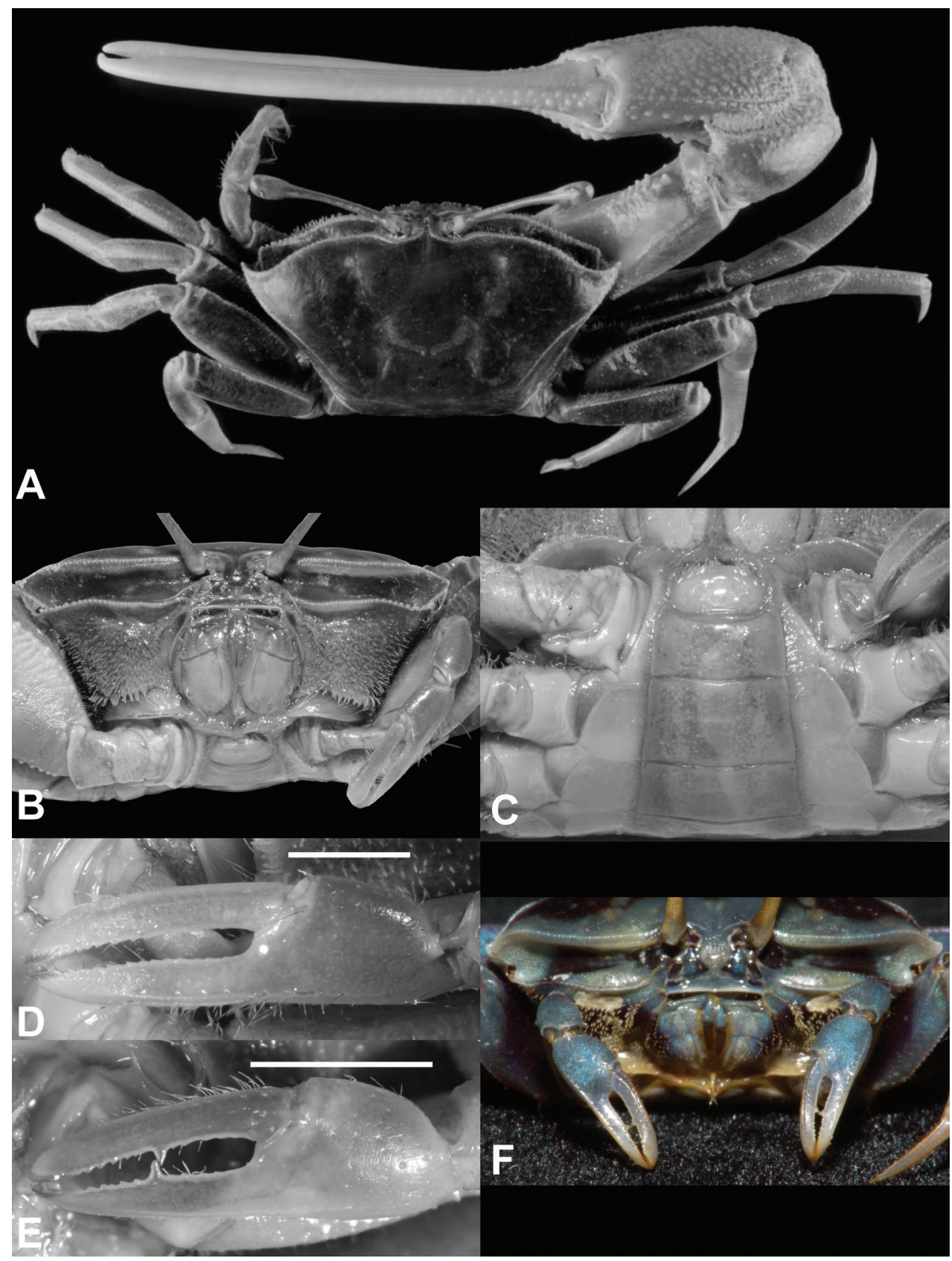

Figure 3. Tubuca alcocki sp. n. A-D holotype (CW $30.1 \mathrm{~mm}$, ZRC 2017.1278) E, F ovigerous female (CW $19.8 \mathrm{~mm}$, NCHUZOOL 14897; Thailand). A dorsal view B frontal view C pleon and telson D, E left minor cheliped $\mathbf{F}$ frontal view, with living colouration. Scale bars: $5.0 \mathrm{~mm}$. 


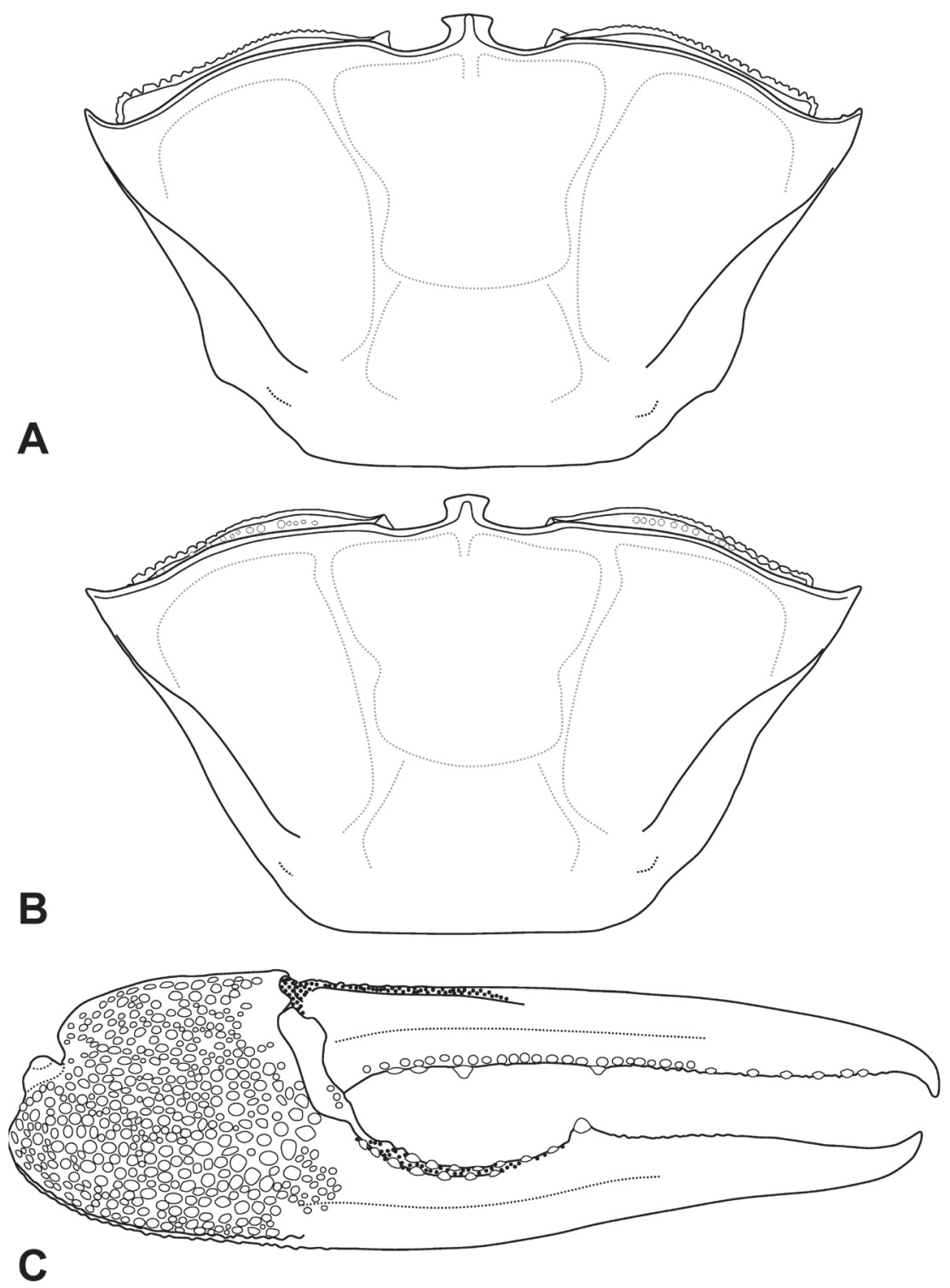

Figure 4. Tubuca alcocki sp. n. A, C holotype (CW $30.1 \mathrm{~mm}$, PL $58.2 \mathrm{~mm}$, ZRC 2017.1278; Thailand); T. urvillei (H. Milne Edwards, 1852) B male (CW 29.7 mm, ZRC 1999.1107; Mayotte). A, B dorsal view $\mathbf{C}$ major cheliped.

dian Ocean. As such, Crane (1975) considered the data on the label to be wrong. Of the three extant type specimens of Gelasimus urvillei $\mathrm{H}$. Milne Edwards, 1852, Crane (1975) selected the male as the lectotype, the other two females becoming paralectotypes (Fig. 1F-G). Crane (1975) considered the male to be an immature specimen (CW $18.5 \mathrm{~mm}$ ) but its G1 is actually already developed (present study). According to Litulo (2005), the smallest ovigerous female from Mozambique is only CW 10.0 
$\mathrm{mm}$. This suggests that the lectotype male, while small is probably already mature. In any case, the G1 of the lectotype of T. urvillei (Crane 1975: fig. 9D) agrees well with the species as is now understood from southeastern Africa (cf. Fig. 5E-H). They also agree in all other morphological characters.

A note on Gelasimus dussumieri H. Milne Edwards, 1852 (at present Tubuca dussumieri) is necessary. The type material of Tubuca dussumieri include specimens from Samarang (Java, Indonesia) and Malabar (Mumbai, India) (H. Milne Edwards, 1852), and as no holotype was originally selected, Crane (1975) designated a male from Samarang as the lectotype of $T$. dussumieri. The paralectotype male from Malabar, however, she reidentified as T. urvillei instead. She also found that T. dussumieri and T. paradussumieri were sympatric in the western Pacific and eastern part of Indian Ocean. She reidentified all the records (including "T. acuta") from western Indian Ocean as T. urvillei, with one exception - the record of G. dussumieri by Hoffmann (1874: pl. 3(22)) and De Man (1891) from Nossy Faly, northern Madagascar, which was referred to T. paradussumieri instead. As no other record of T. paradussumieri from eastern Africa has been reported since 1874 (Crosnier 1965), Crane (1975) regarded this specimen's provenance as questionable. Another record of " $T$. dussumieri" from Bombay, western India (Krishnan 1992) will also need to be confirmed in the future as well. In summary, Crane (1975) emphasized the westernmost distribution of the genus Tubuca (= Deltuca Crane, 1975) should be T. urvillei from southeastern Africa (Tanzania, Madagascar and South Africa), with the species also present in Pakistan and western India. Later, the species was reported from the Red Sea by Hogarth (1986) and Price et al. (1987).

With regard to the records of T. urvillei and T. acuta in Alcock (1900), Crane (1975: 61) considered only those from Pakistan and western India as belonging to true T. urvillei (shown as "(part)" behind these records). That is, she did not think or was uncertain if the records from the Bay of Bengal and the Andaman Sea (e.g. Madras; Sunderbunds; Mergui; Andamans and Nicobars) by Alcock (1900) were also T. urvillei. Lundoer (1974) added a new record of " $U$. angustifrons (De Man, 1892)" from Phuket, Thailand, but this was later reidentified as T. urvillei by Frith et al. (1976) and Frith and Frith (1977a) (see also Frith and Frith 1978; Frith and Brunenmeister 1980, 1983; Jaroensutasinee et al. 2003; Jaroensutasinee and Jaroensutasinee 2004).

\section{Tubuca alcocki sp. $\mathrm{n}$.}

http://zoobank.org/0912FA92-20A2-424F-82C0-A337A20A4494

Figures 3, 4A, C, 5A-D, 6, 7A, C, E, G

Gelasimus Dussumieri H. Milne Edwards, 1852: 148, pl. 4(12) [part; Malabar, India]; Kingsley 1880: 145 [part; list]; Chandy 1973: 402 [Gulf of Kutch, W India] (not Gelasimus dussumieri H. Milne Edwards, 1852 sensu stricto).

Gelasimus acutus - Alcock 1900: 360-361 [Sunderbunds, Mergui; Andamans; Karachi] (not Gelasimus acutus Stimpson, 1858).

Gelasimus Urvillei - Alcock 1900: 362-363 [Nicobars; Madras; Karachi] (not Gelasimus urvillei $\mathrm{H}$. Milne Edwards, 1852). 
Uca angustifrons - Lundoer 1974: 8 [Phuket, SW Thailand]; Ng and Davie 2002: 378

[list; Phuket, SW Thailand] (not Gelasimus signatus var. angustifrons De Man, 1892 = Tubuca bellator (White, 1847)).

Uca (Deltuca) [coarctata] urvillei - Crane 1975: 35, 58-61, figs 8B, 9E, pl. 9C, D [part, Pakistan to southern India]; Frith and Frith 1977a: 100-101 [Phuket, SW Thailand] (not Gelasimus urvillei H. Milne Edwards, 1852).

Uca urvillei - Frith et al. 1976: 14, 19, 23-24, 28 [Phuket, SW Thailand]; Tirmizi and Ghani 1996: 103-105, fig. 39 [Pakistan]; Jaroensutasinee et al. 2003: 1-3 [W Thailand]; Jaroensutasinee and Jaroensutasinee 2004: 534, 538, 540-548 [W Thailand]; Naiyanetr 2007: 133 [list; Thailand]; Saher 2008: 21-22, fig. 2.2, pl. 2.1 [Pakistan]; Dev Roy and Nandi 2012: 218 [Nicobar, India]; Hossain 2015: 203, 1 unnumbered fig. [Bangladesh]; Odhano et al. 2015: 170-171, figs 1-2 [Pakistan] (not Gelasimus urvillei H. Milne Edwards, 1852).

Uca (Deltuca) urvillei - Hogarth 1986: 222-223 [Red Sea]; Price et al. 1987: 456, 464

[Red Sea]; Krishnan 1992: 471-472 [Bombay, India] (not Gelasimus urvillei H. Milne Edwards, 1852).

Uca (Deltuca) dussumieri - Krishnan 1992: 471-472 [Bombay, India] (not Gelasimus dussumieri H. Milne Edwards, 1852)

Uca (Tubuca) urvillei - Beinlich and von Hagen 2006: 10, 14, 25, fig. 7f, k [Thailand; India] (not Gelasimus urvillei H. Milne Edwards, 1852).

Uca (Tubuca) acuta - Trivedi et al. 2015: 27 [Gujarat, India] (not Gelasimus acutus Stimpson, 1858).

Tubuca urvillei - Shih et al. 2016: 159, 174 [part], fig. 12A.

Material examined. Holotype: $\widehat{\delta}$ (CW $30.1 \mathrm{~mm}$, CL $17.9 \mathrm{~mm}$; PL $58.2 \mathrm{~mm}$ ) (ZRC 2017.1278), Ranong mangroves, Thailand, coll. H.-T. Shih et al., 27 May 2012. Para-

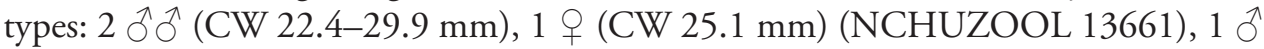

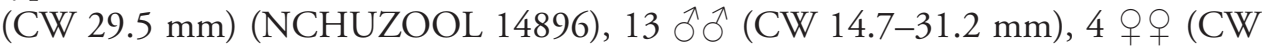
19.9-24.1 mm), 1 ovig. (CW $25.7 \mathrm{~mm}$ ) (NCHUZOOL 14905), same data as holotype; 1 ๙ (CW $24.6 \mathrm{~mm}$ ), 1 ovig. 9 (CW $14.8 \mathrm{~mm})$ (ZRC 2017.1279), Kamphuan mangroves, Ranong, Thailand, 9 Sep. 2000; 1 गे (CW 24.0 mm) (ZRC 2001.2347), Ranong, Thailand, coll. P. Clark, 7 Nov. 2001.

Other material. Thailand: 2 ふึ (CW 17.8-26.1 mm) (ZRC 1988.616-617),

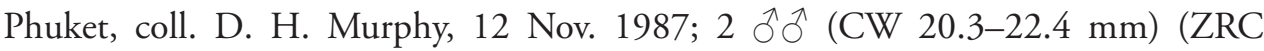
1999.1131), mangrove area south east of Phuket Town ca. $8 \mathrm{~km}$, W. B. Jeffries and H. K. Voris, 14 June 1990; 4 ठ઼ (CW 13.0-16.9 mm), 1 क (CW $18.8 \mathrm{~mm}$ ), 1 ovig.

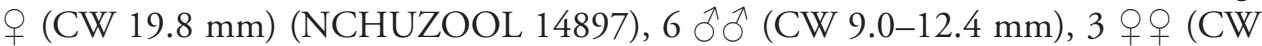
11.4-14.0 mm), 2 ovig. 우 으 (CW 13.9-14.8 mm) (NCHUZOOL 14906), Chalong Bay, Phuket, coll. H.-T. Shih et al., 28 May 2012; 4 ふึ (CW 4.4-16.9 mm), 1 ㅇ (CW $12.8 \mathrm{~mm}), 1$ ovig. ㅇ (CW $14.7 \mathrm{~mm}$ ) (NCHUZOOL 14898), Laem Tukkae, Phuket, coll. H.-T. Shih et al., 29 May 2012; 1 ^ (CW 17.2 mm), 2 우 (CW 14.0-15.6 mm) (NCHUZOOL 14907), Tha Thiap Ruea Bang Rong, Phuket, coll. H.-T. Shih et al., 30 May 2012. India: 1 गे (CW $17.7 \mathrm{~mm}$ ) (NCHUZOOL 14925),

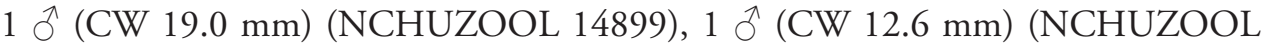



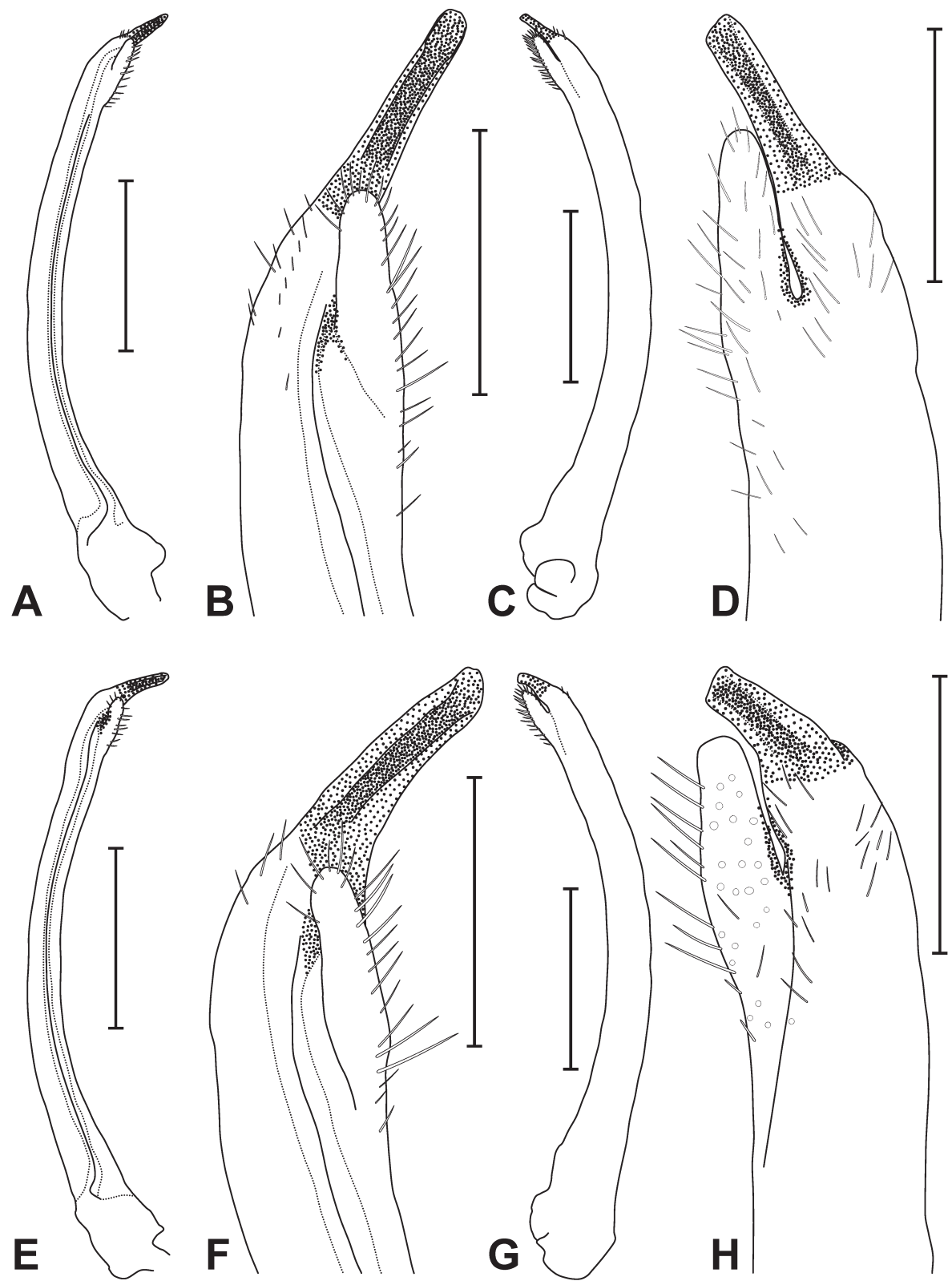

Figure 5. Right G1. Tubuca alcocki sp. n. A-D holotype (CW $30.1 \mathrm{~mm}$, ZRC 2017.1278; Thailand) E-H T. urvillei (H. Milne Edwards, 1852), male (CW 29.7 mm, ZRC 1999.1107; Mayotte). A, E mesial view B, $\mathbf{F}$ mesial view of distal part $\mathbf{C}$, $\mathbf{G}$ lateral view $\mathbf{D}, \mathbf{H}$ lateral view of distal part. Scale bars: A, C, E, G $5.0 \mathrm{~mm} \mathrm{B,} \mathrm{D,} \mathrm{F,} \mathrm{H} 1.0 \mathrm{~mm}$.

14901), 1 ㅇ (CW $17.5 \mathrm{~mm}$ ) (NCHUZOOL 14902), 13 के के (CW 9.9-18.2 mm), 3 우우 (CW 11.4-17.9 mm), 1 ovig. 우 (CW $19.9 \mathrm{~mm}$ ) (NCHUZOOL 14903), Mumbai, coll. H.-N. Chen et al., 17 Mar. 2010; 1 ㅇ (CW 22.6 mm) (NCHUZOOL 14900), Diu mangroves, coll. K. Wong, 20 Mar. 2010. 


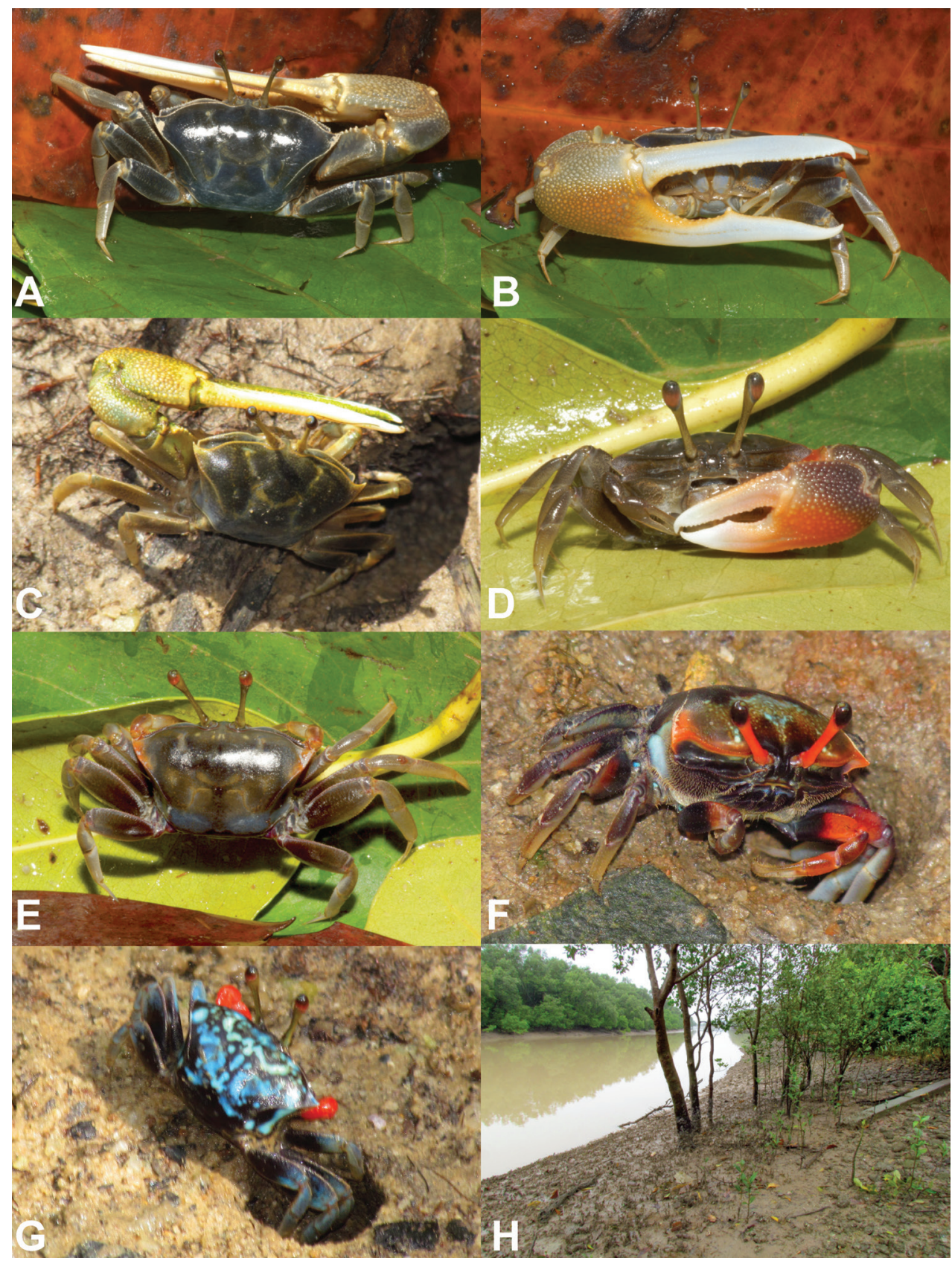

Figure 6. Tubuca alcocki sp. n. A-G variation of the live colouration. A, B holotype (CW $30.1 \mathrm{~mm}$, ZRC 2017.1278; Thailand) $\mathbf{C}$ adult male (not collected; Phuket, Thailand) D young male (CW $13.0 \mathrm{~mm}$, NCHUZOOL 14897; Thailand) E ovigerous female (CW $19.8 \mathrm{~mm}$, NCHUZOOL 14897, Thailand) F, G females in the field (not captured; Phuket, Thailand) $\mathbf{H}$ habitat in Ranong, Thailand. 
Diagnosis. Male. Carapace (Figs 3A, 4A, 6A, C, G, 7A, C, E) trapezoidal, smooth; front narrow, with distinct, narrow median groove; anterolateral angle acutely triangular, directed obliquely anteriorly; anterolateral margin short to moderately long; dorsolateral margin long, definite, strongly converging; one posterolateral stria. Floor of orbit with row of 5-11 tubercles, sometimes with blunt ridge. Major cheliped (Figs 4C, 6B, D) with dactylus usually longer than palm, outer surface of dactylus and pollex each with 1 long groove proximally extending beyond midlength. Fingers of minor cheliped (Figs 3B, D, 6B, D) without conspicuous tooth on either finger. G1 (Fig. 5A-D) with distal tube slender, slightly curved to almost straight, distal and proximal parts subequal in width; thumb of moderate length, extending beyond base of distal tube.

Female. Anterolateral angle more broadly triangular; anterolateral margin moderately long, joining dorsolateral margin as convex structure (Fig. 7G). Floor of orbit with row of 17-19 tubercles (Figs 3F, 6F). Fingers of cheliped (Fig. 3E, F) each with conspicuous tooth on occlusal margin.

Colouration in life. Adults with carapace and legs brown or dark brown, posterior part gray, especially in females (Fig. 6A, C, E). Some females with anterolateral angles orange (Fig. 6E, F) or with dark blotches on blue carapace (Fig. 6G). Major cheliped with fingers white; lower palm deep yellow in large individuals, orange in young individuals; upper palm brown (Fig. 6B-D). Females sometimes with minor chelipeds orange, sometimes with tint of blue (Figs 3F, 6F, G).

Ecological notes. In western Thailand, this species inhabits muddy banks of mangroves (Fig. 6H) and is sympatric with several species of fiddler crabs, including $A u$ struca annulipes ( $\mathrm{H}$. Milne Edwards, 1837), A. bengali, Tubuca forcipata (Adams \& White, 1849) and T. paradussumieri (cf. Frith and Frith 1977a, 1978; this study). In Pakistan, this species is sympatric with Austruca iranica (cf. Saher et al. 2014).

Etymology. This species is named after Alfred William Alcock, who first recorded this species from India and Pakistan as "Uca urvillei" (cf. Alcock 1900).

Distribution. Western Thailand, India, Pakistan, and the Red Sea (see Remarks).

Remarks. Although the number of tubercles on the floor of orbit and thumb morphology of G1 are sometimes useful for distinguishing species of fiddler crabs, they are too variable in Tubuca alcocki sp. n. and T. urvillei (Crane 1975: 58-59; this study) to be used. The two species are similar, but can be morphologically distinguished by the characters of the anterolateral angle of the carapace and G1. The anterolateral angle in male $T$. alcocki is acutely triangular and directed obliquely anteriorly (Fig. 7A, C, E) (vs. relatively broadly triangular in shape and directed more laterally in position in T. urvillei; Fig. 7B, D, F). In female T. alcocki, the anterolateral angle is broadly triangular in shape and the anterolateral margin is relatively longer and curves gently to join the dorsolateral margin (Fig. 7G) (vs. anterolateral angle acutely triangular in shape with the anterolateral margin short and merging with the dorsolateral margin in an almost straight line in T. urvillei; Fig. 7H). The G1 structure is also different. The distal tube of the G1 of $T$. alcocki is proportionately more slender, being slightly curved to almost straight, with the widths of the distal and proximal 


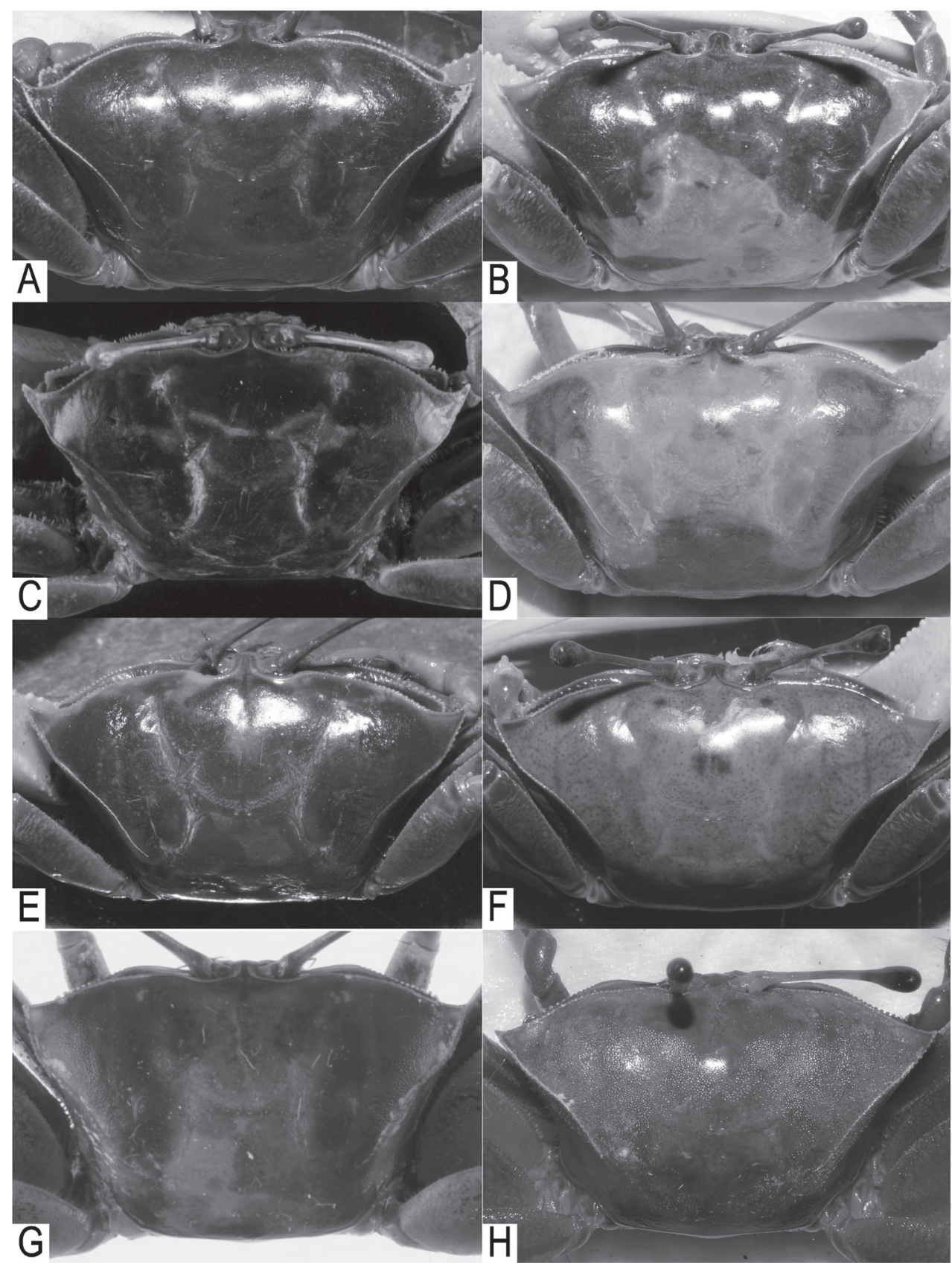

Figure 7. Carapace morphology. A, C, E, G Tubuca alcocki sp. n., B, D, F, H T. urvillei (H. Milne Edwards, 1852). A holotype male (CW $30.1 \mathrm{~mm}$, ZRC 2017.1278; Thailand) B male (CW $34.9 \mathrm{~mm}$, NCHUZOOL 14895; Kenya) C male (CW 29.5 mm, NCHUZOOL 14896; Ranong, Thailand) D male (CW 29.7 mm, ZRC 1999.1107; Mayotte) E male (CW 27.8 mm, NCHUZOOL 14905; Thailand) $\mathbf{F}$ male (CW 27.9 mm, NCHUZOOL 14895; Kenya) G female (CW 22.6 mm, NCHUZOOL 14900; India) $\mathbf{H}$ female (CW 22.9 mm, SMF 19985; Kenya). 
parts subequal (Fig. 5A-D) (vs. distal tube relatively stouter, more distinctly curved and gently tapering towards the tip, with the distal part distinctly narrower than the proximal part in T. urvillei; Fig. 5E-H).

Crane (1975) figured specimens of what she referred to as T. urvillei from southeastern Africa and western India, and they agree with the characters of T. urvillei and T. alcocki, respectively. The anterolateral angles of the male lectotype of T. urvillei (Fig. 1A; Crane 1975: pl. 9E) and the male specimen from Tanzania (Crane 1975: fig. $7 \mathrm{~A}$ ) are both broadly triangular. In addition, the G1 distal tubes of the lectotype of T. urvillei as well as those from Somalia and Madagascar figured by Vannini and Valmori (1981: fig. 6F) and Crosnier (1965: figs 195-196) are all relatively stout, curved and tapering towards the tip. As such the material from Tanzania, Somalia and Madagascar should all be referred to T. urvillei sensu stricto.

The specimen from Malabar, western India, and one of the paralectotypes of Gelasimus dussumieri (see discussion earlier), have the G1 distal tube relatively more slender, almost straight, with the distal and proximal parts subequal in width (Crane 1975: fig. 9E) and are thus is clearly referable to T. alcocki. The G1 structures of specimens from Pakistan (Saher 2008: fig. 2.2; Tirmizi and Ghani 1996: fig. 39) also match that of T. alcocki. Interestingly, Hogarth (1986) reported "Uca (Deltuca) urvillei" from the Red Sea, which was a new record of this species for this region, but without any figure or description. The first author has examined specimens from the Red Sea and they are clearly T. alcocki as well (H-T Shih and BA Kumar, in preparation). The distribution of T. alcocki thus stretches from the northern part of the Indian Ocean (Red Sea) to the Arabian Sea and Andaman Sea.

There are also colour differences between T. urvillei and T. alcocki. While the colouration of females, young males, and juveniles are variable in Tubuca species, the colouration of the adult male carapace is generally more useful (Crane 1975; von Hagen and Jones 1989; Beinlich and von Hagen 2006). Adult male T. urvillei sensu stricto have various degrees of blue on the carapace and ambulatory legs (Fig. 2D, E), with the palm of the major cheliped ochraceous to apricot brown (Fig. 2D); while young and females sometimes have pale and dark blotches on a blue background (Fig. 2F). In adult male T. alcocki, the dorsal surface of the carapace is always dark brown (Fig. 6A, C) whereas in T. urvillei, it is always blue (Fig. 2D, E).

\section{DNA analyses and discussion}

The molecular analyses include 12 specimens of Tubuca alcocki sp. n. from western Thailand and western India; and three specimens of T. urvillei from southeastern Africa (Table 1). The phylogenetic tree (Fig. 8) based on COI shows that specimens from southeastern Africa form a distinct clade, sister to another clade with material from western India and western Thailand. The genetics therefore supports the recognition of two species. Only one haplotype is found from T. urvillei from southeastern Africa, with two haplotypes from T. alcocki. 


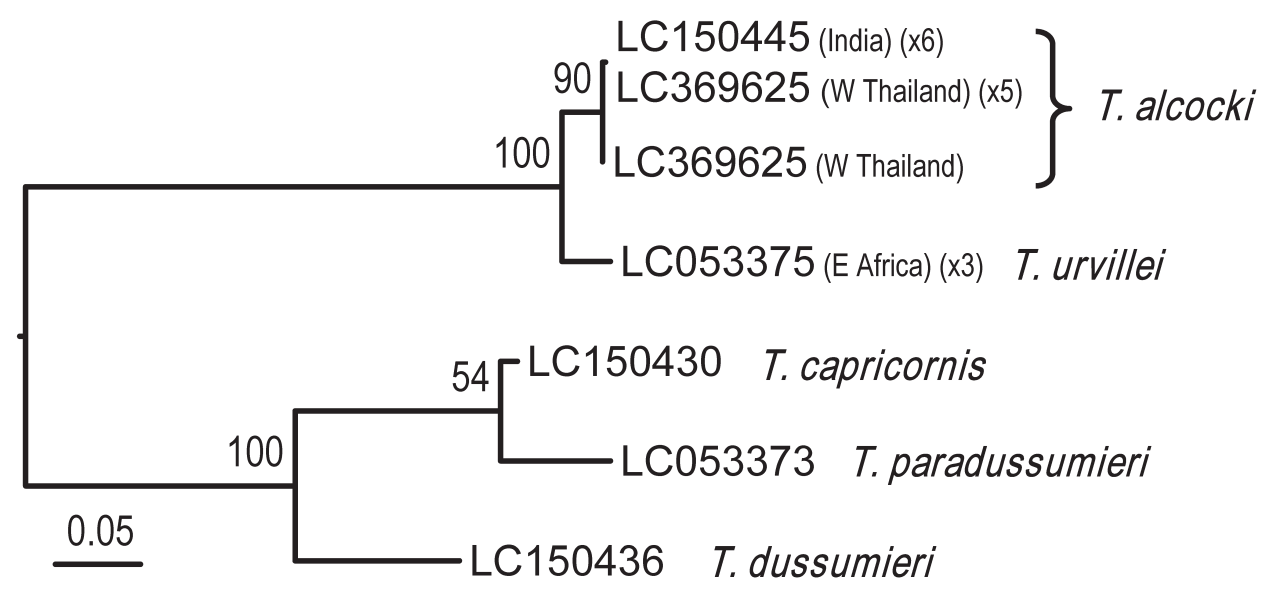

Figure 8. A maximum likelihood (ML) tree for Tubuca urvillei (H. Milne Edwards, 1852) and T. alcocki sp. n. from the Indian Ocean, and outgroups, based on COI gene. Bootstrap proportions are shown at the nodes. For accession numbers, see Table 1 and Materials and methods.

The genetic distance between these two sister species is $3.78 \%$ (K2P distance) or $3.65 \%$ (p-distance), and the total bp difference is $24 \mathrm{bp}$. The value is higher than some species within the Ocypodoidea, e.g., the minimum genetic distance of K2P between two species is $2.79 \%$ between Paraleptuca crassipes (White, 1847) and P. splendida (Stimpson, 1858); 3.62 \% between Gelasimus hesperiae (Crane, 1975) and "Clade U"; and $3.62 \%$ between Mictyris brevidactylus Stimpson, 1858 and M. guinotae Davie, Shih \& Chan, 2010, but still smaller than $6.25 \%$ between Ocypode stimpsoni Ortmann, 1897 and O. mortoni George, 1982; and $4.43 \%$ between Scopimera globosa (De Haan, 1835) and S. ryukyuensis Wong, Chan \& Shih, 2010 (see Davie et al. 2010; Shih et al. 2010, 2012; Wong et al. 2010, 2012; Chu et al. 2015).

Tubuca alcocki and T. urvillei are quite similar in general morphology, but can be still distinguished by characters of the carapace and G1 (see Remarks under T. alcocki), which is supported by molecular evidence (Fig. 8). As a result, T. alcocki can be considered a pseudocryptic species (i.e., minor morphological difference, only after other methods have unveiled their existence), which is not uncommon in marine organisms (Knowlton 1993, 2000), including brachyuran crabs (Ragionieri et al. 2009, 2012; Shih et al. 2013a; Ng and Shih 2014; Lai et al. 2017).

According to Shih et al. (2016) and this study, the clade of T. urvillei and T. alcocki is sister to the clade composed of T. dussumieri, T. paradussumieri and T. capricornis. From the distributional patterns of these two main clades, while T. urvillei and T. alcocki are found only in the Indian Ocean, another main clade, composed of $T$. dussumieri, T. paradussumieri and T. capricornis (Shih et al. 2016), is primarily western Pacific, although T. alcocki and T. paradussumieri are sympatric in the eastern Indian Ocean (Frith and Frith 1977a, 1978; present study). Because T. dussumieri has been recorded from Surin Islands, Phang Nga Province, Thailand (Frith and Frith 1977a, b, 1978), T. alcocki is probably also sympatric with it. 
Hogarth (1986) has emphasized that the Red Sea population of "T. urvillei" is discontinuous with other populations and represents a significant extension of the known range. His Red Sea material is now recognized as T. alcocki (unpublished data; see Remarks under T. alcocki), and the northernmost distribution of T. urvillei sensu stricto is in southern Somalia (Crane 1975; Hogarth 1986). Tubuca alcocki thus has a wider range, which includes most of the northern Indian Ocean, from western Thailand (facing the Andaman Sea), through the Bay of Bengal and India, to the Red Sea. Tubuca urvillei, on the other hand, is known with certainty only from southeastern Africa. This distributional pattern is probably caused by the major oceanographic circulation systems at around $10^{\circ} \mathrm{S}$, which limit the dispersal of larvae to the southeastern African coastline (Tsang et al. 2012).

Based on the pairwise divergence rates of $1.66 \%$ per million years for COI of marine coastal crabs (Schubart et al. 1998), T. urvillei and T. alcocki diverged $2.2 \pm 0.4$ million years ago (mya) (with uncorrected p-distance divergences of $3.65 \% \pm 0.71$ $\%)$ around the beginning of the Pleistocene. The divergence between them is probably caused by the change of larval dispersal routes through ocean currents (e.g., the Equatorial Counter Current for a biogeographic barrier of barnacles; Tsang et al. 2012), which was likely influenced by the extreme climate during the glaciation periods in the Pleistocene (Shih et al. 2013a).

\section{Acknowledgements}

This study was supported by a grant from the Ministry of Science and Technology (MOST 105-2621-B-005-002-MY3), Executive Yuan, Taiwan, to HTS. We wish to thank Kingsley Wong, Hsi-Nien Chen, Ng Ngan Kee, Lee Bee Yan, Tan Siong Kiat, for helping specimen collection in the field; for providing specimen used in this study; Laure Corbari, late Michael Türkay, Stefano Cannicci and Sara Fratini for providing specimens used in this study; S. Cannicci and Joseph Poupin for providing photographs; Anand. Jeya Kumar for specimen information from the Red Sea; and Pei-Yi Hsu for measuring specimens and part of molecular work. Special thanks are due to Somsak Panha (Chulalongkorn University) and Somchai Bussarawit (previously from the Phuket Marine Biological Centre) for help with work in western Thailand over the years. We acknowledge Tomoyuki Komai and one anonymous referee, who greatly improved this manuscript.

\section{References}

Alcock A (1900) Materials for a carcinological fauna of India. No. 6. The Brachyura Catometopa or Grapsoidea. Journal of the Asiatic Society of Bengal 69: 279-456.

Barnard KH (1950) Descriptive catalogue of South African decapod Crustacea. Annals of the South African Museum 38: 1-837.

Beinlich B, von Hagen HO (2006) Materials for a more stable subdivision of the genus $U_{c a}$ Leach. Zoologische Mededelingen 80: 9-32. 
Bott R (1973) Die verwandtschaftlichen Beziehungen der Uca-Arten. Senckenbergiana Biologica 54: 315-325.

Bouchard JM, Poupin J, Cleva R, Dumas J, Dinhut V (2013) Land, mangrove and freshwater decapod crustaceans of Mayotte region (Crustacea Decapoda). Atoll Research Bulletin 592: 1-60. https://doi.org/10.5479/si.00775630.592

Chandy M (1973) New records of Brachyuran decapods from the Gulf of Kutch. Journal of the Bombay Natural History Society 70: 401-402.

Chu KH, Schubart CD, Shih HT, Tsang LM (2015) Genetic diversity and evolution of Brachyura. In: Castro P, Davie PJF, Guinot D, Schram F, Von Vaupel Klein C (Eds) Treatise on Zoology - Anatomy, Taxonomy, Biology - The Crustacea, complementary to the volumes translated from the French of the Traité de Zoologie, 9(C)(I), Decapoda: Brachyura (Part 1): 775-820. https://doi.org/10.1163/9789004190832_016

Crane J (1975) Fiddler crabs of the world (Ocypodidae: genus $U_{c a}$ ). Princeton University Press, Princeton, New Jersey, 736 pp.

Crosnier A (1965) Crustacés Décapodes Grapsidae et Ocypodidae. Faune de Madagascar 18: 1-143. [pls 1-11]

Davie PJF, Guinot D, Ng PKL (2015) Anatomy and functional morphology of Brachyura. In: Castro P, Davie PJF, Guinot D, Schram F, Von Vaupel Klein C (Eds) Treatise on Zoology Anatomy, Taxonomy, Biology - The Crustacea, complementary to the volumes translated from the French of the Traité de Zoologie, 9(C)(I), Decapoda: Brachyura (Part 1), 11-163. https://doi.org/10.1163/9789004190832_004

Davie PJF, Shih HT, Chan BKK (2010) A new species of Mictyris (Decapoda, Brachyura, Mictyridae) from the Ryukyu Islands, Japan. Crustaceana Monographs 11: 83-105. https://doi.org/10.1163/ej.9789004170865.i-366.61

Dev Roy MK, Nandi NC (2012) Brachyuran crabs (Crustacea). Fauna of Andaman and Nicobar Islands, State Fauna Series, 19(1). Zoological Survey of India. Kolkata, India: 185-236. Fourmanoir P (1954) Crabes de la côte ouest de Madagascar. Le Naturaliste Malgache 6: 1-16. Frith DW, Brunenmeister S (1980) Ecological and population studies of fiddler crabs (Ocypodidae, genus $U_{c a}$ ) on a mangrove shore at Phuket Island, western Peninsular Thailand. Crustaceana 39: 157-184. https://doi.org/10.1163/156854080X00067

Frith DW, Brunenmeister S (1983) Fiddler crab (Ocypodidae: genus $U c a$ ) size, allometry and male major chela handedness and morphism on a Thailand mangrove shore. Phuket Marine Biological Center Research Bulletin 29: 1-15.

Frith DW, Frith CB (1977a) Range extensions of fiddler crabs (Decapoda, Brachyura, Ocypodidae) in the north-western Malay Peninsula area. Crustaceana 32: 100-102. https://doi.org/10.1163/156854077X00944

Frith DW, Frith CB (1977b) Observations on fiddler crabs (Ocypodidae: genus Uca) on Surin Island, western peninsular Thailand, with particular reference to Uca tetragonon (Herbst). Phuket Marine Biological Center Research Bulletin 18: 1-14.

Frith DW, Frith CB (1978) Notes on the ecology of fiddler crab populations (Ocypodidae: genus Uca) on Phuket, Surin Nua and Yao Yai Islands, western peninsular Thailand. Phuket Marine Biological Center Research Bulletin 25: 1-13.

Frith DW, Tantanasiriwong R, Bhatia O (1976) Zonation of macrofauna on a mangrove shore, Phuket Island. Phuket Marine Biological Center Research Bulletin 10: 1-37. 
Ghory FS, Siddiqui FA (2006) A comparative study of the first zoeal stage of Uca urvillei and Uca annulipes (Crustacea: Brachyura: Ocypodidae) reared in the laboratory. Turkish Journal of Zoology 30: 161-166.

Hagen HO von, Jones DS (1989) The fiddler crabs (Ocypodidae: Uca) of Darwin, Northern Territory, Australia. Beagle, Records of the Northern Territory Museum of Arts and Sciences 6: 55-68.

Hartnoll RG (1975) The Grapsidae and Ocypodidae (Decapoda: Brachyura) of Tanzania. Journal of Zoology 177: 305-328. https://doi.org/10.1111/j.1469-7998.1975.tb02235.x

Hilgendorf F (1869) Crustaceen. In: Decken BCCvd (Ed.) Reisen in Ost-Afrika in den Jahren 1859-1865. C. F. Winter'sche Verlagshandlung, Leipzig, Heidlberg 3: 67-116, 147.

Hoffmann CK (1874) Crustacés et echinodermes de Madagascar et de l'ile de la Runion. In: Pollen FPL, Van Dam DC (Eds) Recherches sur la Fauna de Madagascar et de ses dépendances, part 5. E. J. Brill, Leiden, 1-58. [pls 1-10]

Hogarth PJ (1986) Occurrence of Uca (Deltuca) urvillei (H. Milne Edwards, 1852) in the Saudi Red Sea (Decapoda, Ocypodidae). Crustaceana 51: 222-223. https://doi. org/10.1163/156854086X00737

Hossain MAR (Ed.) (2015) Red List of Bangladesh, volume 6: Crustaceans. IUCN, International Union for Conservation of Nature, Bangladesh Country Office, Dhaka, 256 pp.

Jaroensutasinee M, Jaroensutasinee K (2004) Morphology, density, and sex ratio of fiddler crabs from southern Thailand (Decapoda, Brachyura, Ocypodidae). Crustaceana 77: 533-551. https://doi.org/10.1163/1568540041718000

Jaroensutasinee M, Kaenphet A, Jaroensutasinee K (2003) Geographic variation in morphology population density adult sex ratio in nine species of fiddler crabs in southern Thailand. $29^{\text {th }}$ Congress on Science \& Technology of Thailand, 1-3.

Kensley B (1981) On the zoogeography of southern African decapod Crustacea, with a distributional checklist of the species. Smithsonian Contributions to Zoology 338: 1-64. https://doi.org/10.5479/si.00810282.338

Kimura M (1980) A simple method for estimating evolutionary rates of base substitutions through comparative studies of nucleotide sequences. Journal of Molecular Evolution 16: 111-120. https://doi.org/10.1007/BF01731581

Kingsley JS (1880) Carcinological notes, no. II. - Revision of the Gelasimi. Journal of the Academy of Natural Sciences of Philadelphia 1880: 135-155.

Knowlton N (1993) Sibling species in the sea. Annual Review of Ecology and Systematics 24: 189-216. https://doi.org/10.1146/annurev.es.24.110193.001201

Knowlton N (2000) Molecular genetic analyses of species boundaries in the sea. Hydrobiologia 420: 73-90. https://doi.org/10.1023/A:1003933603879

Krauss F (1843) Die Südafrikanischen Crustaceen. Eine Zusammenstellung aller bekannten Malacostraca, Bemerkungen über deren Lebensweise und Geographische Verbreitung, nebst Beschreibung und Abbildung mehrer neuen Arten. Stuttgart, E. Schweizerbartische Verlagsbuchhandlung, 68 pp. [4 pls]

Krishnan S (1992) Distribution of fiddlers in India. Records of the Zoological Survey of India 91: 471-474.

Kumar S, Stecher G, Tamura K (2016) MEGA7: Molecular Evolutionary Genetics Analysis version 7.0 for bigger datasets. Molecular Biology and Evolution 33: 1870-1874. https://doi.org/10.1093/molbev/msw054 
Lai JCY, Shih HT, Ng PKL (2017) The systematics of land crabs of the genus Gecarcoidea H. Milne Edwards, 1837, and recognition of a pseudocryptic species, G. humei (Wood-Mason, 1874) from the eastern Indian Ocean (Crustacea: Decapoda: Gecarcinidae). Invertebrate Systematics 31: 406-426. https://doi.org/10.1071/IS16052

Lenz H (1910) Crustaceen von Madagaskar, Ostafrika und Ceylon. In: Voeltzkow A (Ed.) Reise in Ostafrkia in den Jahren 1903-1905 2: 539-576.

Lenz H, Richters F (1881) Beitrag zur Krustaceenfauna von Madagascar. Abhandlungen der Senckenbergischen Naturforschenden Gesellschaft 12: 421-428.

Litulo C (2005) Population structure and reproductive biology of the fiddler crab Uca urvillei (Brachyura: Ocypodidae) in Maputo Bay (south Mozambique). Journal of Natural History 39: 2307-2318. https://doi.org/10.1080/00222930502005688

Lundoer S (1974) A checklist of the marine Brachyura in the reference collection at PMBC, Thailand. Phuket Marine Biological Center Research Bulletin 4: 3-11.

Maccagno T (1928) Crostacei decapodi. Le specie del genere $U c a$ Leach conservate nel Regio Museo Zoologico di Torino. Bollettino dei Musei di Zoologia ed Anatomia comparata della R. Universit di Torino 41(11): 1-52.

Macnae W (1963) Mangrove swamps in South Africa. Journal of Ecology 51: 1-25. https:// doi.org/10.2307/2257502

Man JG De (1880) On some species of Gelasimus Latr. and Macrophthalmus Latr. Notes from the Leyden Museum 2: 67-72.

Man JG De (1891) Carcinological studies in the Leyden Museum. No. 5. Notes from the Leyden Museum 13: 1-61.

Milne Edwards H (1852) Observations sur les affinités zoologiques et la classification naturelle des Crustacés. Annales des Sciences Naturelles, Zoology 3(18): 109-166.

Milne-Edwards A (1868) Description de quelques crustacés nouveaux provenant des voyages de M. Alfred Grandidier a Zanzibar et a Madagascar. Nouvelles Archives du Muséum d'Histoire Naturelle, Paris 4: 69-92. [pls 19-21]

Naderloo R, Schubart CD, Shih HT (2016) Genetic and morphological separation of Uca occidentalis, a new East African fiddler crab species, from $U c a$ annulipes (H. Milne Edward, 1837) (Crustacea: Decapoda: Brachyura: Ocypodidae). Zoologischer Anzeiger 262: 10-19. https://doi.org/10.1016/j.jcz.2016.03.010

Naiyanetr P (2007) Checklist of crustacean fauna in Thailand (Decapoda, Stomatopoda, Anostraca, Myodocopa and Isopoda). Office of Natural Resources and Environmental Policy and Planning, Bangkok, Thailand, $196 \mathrm{pp}$.

Ng PKL, Davie PJF (2002) A checklist of the brachyuran crabs of Phuket and western Thailand. Phuket Marine Biological Center Research Bulletin 23: 369-384.

$\mathrm{Ng}$ PKL, Shih HT (2014) The systematics of the land crabs of the Discoplax hirtipes (Dana, 1851) species-group (Crustacea: Decapoda: Brachyura: Gecarcinidae), with description of a new species from the eastern Indian Ocean. Raffles Bulletin of Zoology, Supplement 30: 109-135.

Odhano S, Saher NU, Kamal M (2015) An over clawed (with two enlarge chela) male crab of Uca urvillei (Ocypodidae: Tubuca: Uca) along the coast of Karachi, Pakistan. Biharean Biologist 9(2): 170-172.

Ortmann AE (1894) Crustaceen. In: Semon R (Ed.) Zoologische Forschungsreisen in Australien und dem Malayischen Archipel. Denkschriften der Medicinisch-Naturwissen- 
schaftlichen Geselschaft zu Jena. Verlag von Gusta Fischer, Jena, Germany 8: 3-80. https://doi.org/10.5962/bhl.title.10506

Peer N, Miranda NAF, Perissinotto R (2015) A review of fiddler crabs (genus Uca Leach, 1814) in South Africa. African Zoology 50(3): 187-204. https://doi.org/10.1080/15627020.20 15.1055700

Peer N, Perissinotto R, Taylor RH, Miranda NAF (2014) Temporal variations in the diversity of true crabs (Crustacea: Brachyura) in the St Lucia Estuary, South Africa. African Invertebrates 55(1): 39-65. https://doi.org/10.5733/afin.055.0103

Pfeffer G (1889) Übersicht der von Herrn Dr. F. Stuhlmann in Ägypten, auf Sansibar und dem gegenüberliegenden Festlande gesammelten Reptilien, Amphibien, Fische, Mollusken und Krebse. Jahrbuch der Hamburgischen Wissenschaftlichen Anstalten 6: 1-36.

Price ARG, Medley PAH, McDowall RJ, Dawson-Shepherd AR, Hogarth PJ, Ormond RFG (1987) Aspects of mangal ecology along the Red Sea coast of Saudi Arabia. Journal of Natural History 21: 449-464. https://doi.org/10.1080/00222938700771121

Ragionieri L, Fratini S, Vannini M, Schubart CD (2009) Phylogenetic and morphometric differentiation reveal geographic radiation and pseudo-cryptic speciation in a mangrove crab from the Indo-West Pacific. Molecular Phylogenetics and Evolution 52: 825-834. https://doi.org/10.1016/j.ympev.2009.04.008

Ragionieri L, Fratini S, Schubart CD (2012) Revision of the Neosarmatium meinerti species complex (Decapoda: Brachyura: Sesarmidae), with descriptions of three pseudocryptic Indo-West Pacific species. Raffles Bulletin of Zoology 60: 71-87.

Richmond MD (1997) A guide to the seashores of eastern Africa and the western Indian Ocean Islands. Sida/SAREC, Stockholm, Sweden, $448 \mathrm{pp}$.

Rosenberg MS (2001) The systematics and taxonomy of fiddler crabs: a phylogeny of the genus Uca. Journal of Crustacean Biology 21: 839-869. https://doi.org/10.1163/2002197599990176

Saher NU (2008) Population dynamics and biology of fiddler crabs in the mangrove areas of Karachi coast. Karachi, Pakistan, University of Karachi. PhD Thesis, University of Karachi, Karachi, 336 pp.

Saher NU, Sahir O, Shih HT, Kamal M, Qureshi NA (2014) On a new record of the genus Uca (Decapoda, Brachyura, Ocypodidae) found along the coast of Pakistan. Crustaceana 87: 666-673. https://doi.org/10.1163/15685403-00003317

Schubart CD, Diesel R, Hedges SB (1998) Rapid evolution to terrestrial life in Jamaican crabs. Nature 393: 363-365. https://doi.org/10.1038/30724

Serbino NMB (2008) Descrição do primeiro estágio larval de Uca urvillei (H. Milne Edwards, 1852) (Brachyura: Ocypodidae). Revista Inter Texto 1: 62-72.

Shih HT, Kamrani E, Davie PJF, Liu MY (2009) Genetic evidence for the recognition of two fiddler crabs, Uca iranica and U. albimana (Crustacea: Brachyura: Ocypodidae), from the northwestern Indian Ocean, with notes on the U. lactea species-complex. Hydrobiologia 635: 373-382. https://doi.org/10.1007/s10750-009-9930-6

Shih HT, Komai T, Liu MY (2013a) A new species of fiddler crab from the Ogasawara (Bonin) Islands, Japan, separated from the widely-distributed sister species Uca (Paraleptuca) crassipes (White, 1847) (Crustacea: Decapoda: Brachyura: Ocypodidae). Zootaxa 3746: 175-193. https://doi.org/10.11646/zootaxa.3746.1.8 
Shih HT, Naruse T, Ng PKL (2010) Uca jocelynae sp. nov., a new species of fiddler crab (Crustacea: Brachyura: Ocypodidae) from the Western Pacific. Zootaxa 2337: 47-62.

Shih HT, Ng PKL, Davie PJF, Schubart CD, Türkay M, Naderloo R, Jones DS, Liu MY (2016) Systematics of the family Ocypodidae Rafinesque, 1815 (Crustacea: Brachyura), based on phylogenetic relationships, with a reorganization of subfamily rankings and a review of the taxonomic status of $U_{c a}$ Leach, 1814, sensu lato and its subgenera. Raffles Bulletin of Zoology 64: 139-175.

Shih HT, Ng PKL, Liu MY (2013b) Systematics of the Indo-West Pacific broad-fronted fiddler crabs (Crustacea: Ocypodidae: genus Uca). Raffles Bulletin of Zoology 61: 641-649.

Shih HT, Ng PKL, Wong KJH, Chan BKK (2012) Gelasimus splendidus Stimpson, 1858 (Crustacea: Brachyura: Ocypodidae), a valid species of fiddler crab from the northern South China Sea and Taiwan Strait. Zootaxa 3490: 30-47.

Shih HT, Saher NU, Kamrani E, Ng PKL, Lai YC, Liu MY (2015) Population genetics of the fiddler crab Uca sindensis (Alcock, 1900) (Crustacea: Brachyura: Ocypodidae) from the Arabian Sea. Zoological Studies 54: 1. https://doi.org/10.1186/s40555-014-0078-3

Stamatakis A (2006) RAxML-VI-HPC: maximum likelihood-based phylogenetic analyses with thousands of taxa and mixed models. Bioinformatics 22: 2688-2690. https://doi.org/10.1093/ bioinformatics/btl446

Stebbing TRR (1905) South African Crustacea. Part III. Marine Investigations in South Africa 4: 21-120.

Stebbing TRR (1910) General catalogue of South African Crustacea. (Part V of S. A. Crustacea, for the marine investigations in South Africa). Annals of the South African Museum 6: 281-593. [pls 15-22]

Stebbing TRR (1917) South African Crustacea (Part IX. of S. A. Crustacea, for the Marine Investigations in South Africa). Annals of Durban Museum 2: 1-33, pls 1-6.

Tirmizi NM, Ghani N (1996) Marine fauna of Pakistan: 5, Crustacea: Brachyura, Brachyrhyncha, Part 1. (Xanthidae, Goneplacidae, Pinnotheridae, Ocypodidae, Grapsidae). Publication of the Centre of Excellence in Marine Biology, University of Karachi, Karachi, Pakistan, 188 pp.

Trivedi DJ, Trivedi JN, Soni GM, Purohit BD, Vachhrajani K (2015) Crustacean fauna of Gujarat state of India: a review. Electronic Journal of Environmental Sciences 8: 23-31.

Tsang LM, Achituv Y, Chu KH, Chan BKK (2012) Zoogeography of intertidal communities in the West Indian Ocean as determined by ocean circulation systems: patterns from the Tetraclita barnacles. PLoS One 7: e45120. https://doi.org/10.1371/journal.pone.0045120

Vannini M, Valmori P (1981) Researches on the coast of Somalia. The shore and dune of Sar Uanle. 31. Ocypodidae and Gecarcinidae (Decapoda Brachyura). Monitore Zoologico Italiano (N. S.) 14: 199-226.

Wong KJH, Chan BKK, Shih HT (2010) Taxonomy of the sand bubbler crabs Scopimera globosa De Haan, 1835, and S. tuberculata Stimpson, 1858 (Crustacea: Decapoda: Dotillidae) in East Asia, with description of a new species from the Ryukyus, Japan. Zootaxa 2345: 43-59.

Wong KJH, Shih HT, Chan BKK (2012) The ghost crab Ocypode mortoni George, 1982 (Crustacea: Decapoda: Ocypodidae): redescription, distribution at its type locality, and the phylogeny of East Asian Ocypode species. Zootaxa 3550: 71-87. 